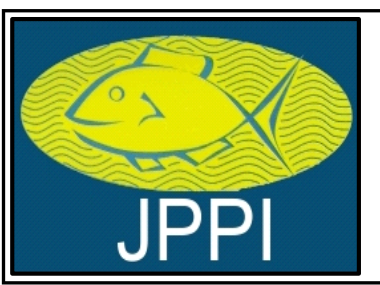

Tersedia online di: http://ejournal-balitbang.kkp.go.id/index.php/jppi
e-mail:jppi.puslitbangkan@gmail.com

JURNAL PENELITIAN PERIKANANINDONESIA

Volume 24 Nomor 3 September 2018

p-ISSN: 0853-5884

e-ISSN: 2502-6542

Nomor Akreditasi RISTEKDIKTI: 21/E/KPT/2018

\title{
VARIASI GENETIK MADIDIHANG \\ (Thunnus albacares; Bonnaterre, 1788) DENGAN ANALISIS MIKROSATELIT DI PERAIRAN INDONESIA
}

\section{GENETIC VARIATION OF YELLOWFIN TUNA \\ (Thunnus albacares; Bonnaterre, 1788) WITH MICROSATELLITE ANALYSIS IN INDONESIAN WATERS}

\author{
Irwan Jatmiko*1, Fathur Rochman' ${ }^{1}$ dan Maya Agustina ${ }^{1}$ \\ ${ }^{1}$ Loka Riset Perikanan Tuna, Jl. Mertasari 140 Sidakarya, Denpasar, Bali-80224, Indonesia \\ Teregistrasi I tanggal: 29 Agustus 2017; Diterima setelah perbaikan tanggal: 21 Februari 2018; \\ Disetujui terbit tanggal: 02 Maret 2018
}

\begin{abstract}
ABSTRAK
Madidihang (Thunnus albacares) merupakan spesies yang bermigrasi jauh yang distribusinya di perairan tropis hingga perairan subtropis. Spesies ini ditemukan di Samudra Atlantik, Hindia dan Pasifik. Informasi genetik ikan dengan migrasi jauh seperti tuna penting diketahui untuk kepentingan pemanfaatan secara lestari. Penelitian ini bertujuan untuk memperoleh informasi keragaman genetik dan struktur populasi yang dieksploitasi dan kekerabatan populasi madidihang di perairan Indonesia. Pengumpulan sampel genetik dilakukan di tiga lokasi yaitu di Barat Sumatra, Selatan Bali dan perairan Sulawesi Utara. Metode yang digunakan adalah analisis mikrosatelit yang terdiri dari ekstraksi, purifikasi, amplifikasi polymerase chain reaction (PCR) dan elektroforesis. Hasil analisis terhadap 3 loci DNA mikrosatelit menunjukkan bahwa tingkat kekerabatan ketiga kelompok sampel relatif dekat yaitu berkisar antara 0,132-0,206. Hal ini menunjukkan bahwa Populasi madidihang di perairan Indonesia merupakan stok tunggal dan terjadi perkawinan acak. Meskipun demikian, sebagai spesies yang bermigrasi jauh lintas negara, pengelolaan madidihang juga memerlukan kerjasama yang baik antar negara yang tergabung dalam organisasi pengelolaan perikanan tuna regional.
\end{abstract}

Kata Kunci: Keragaman genetik; struktur populasi; analisis mikrosatelit

\begin{abstract}
Yellowfin tuna (Thunnus albacares) is a highly migratory species that distribute from tropical to subtropical waters. This species can be found in the Atlantic, Indian and Pacific Oceans. Genetic information in fish with long distance migration such as tuna is very important for sustainable use. This study aims to obtain information on genetic diversity and population structure exploited and kinship of yellowfin tuna populations in Indonesian waters. Genetic sampling of yellowfin tuna was conducted in three locations in Indonesian waters in western Sumatra, southern Bali and North Sulawesi waters. The methods used was microsatellite analysis which consist of extraction, purification, polymerase chain reaction (PCR) amplification and electrophoresis. The result of 3 microsatellite DNA locus analysis showed that the level of kinship between the three sample groups in Indonesian waters was relatively close, ranging from 0.132 to 0.206 . This shows that yellowfin tuna population in Indonesian waters is a single stock and random copulation. However, as a highly migratory species that migrate across the nations, yellowfin tuna management also requires good cooperation among countries incorporated in regional tuna fisheries management organizations.
\end{abstract}

Keywords: Genetic variation; population structure; microsatellite analysis 


\section{PENDAHULUAN}

Informasi genetik pada ikan dengan migrasi yang tinggi seperti tuna penting diketahui untuk landasan pemanfaatan yang lestari. Selain itu, informasi genetik juga dapat mendukung pengelolaan stok ikan secara lestari dan berkesinambungan (Santos et al., 2006). Penelitian tentang genetika populasi tuna telah dilakukan di seluruh dunia menggunakan metode yang berbeda-beda seperti PCR-RFLP (Nugraha et al., 2010), sekuens mitokondria (Chiang et al., 2008; Pertiwi et al., 2014) dan mikrosatelit (Gonzalez et al., 2008). Penelitian tentang genetika populasi madidihang menggunakan metode mikrosatelit masih terbatas dilakukan oleh peneliti Indonesia.

Analisis mitokondria DNA pada sampel madidihang di sekitar perairan India, menunjukkan tidak adanya perbedaan struktur populasi madidihang (Kunal et al., 2014). Kelemahan analisis ini adalah membutuhkan sampel yang sangat banyak dengan kualitas DNA yang baik. Beberapa studi penelitian sebelumnya tentang struktur populasi madidihang di Samudra Hindia, menunjukkan tidak ditemukan hasil yang signifikan perbedaan subpopulasi (Chow et al., 2000; Nishida et al., 2001). Wu et al. (2010), menunjukkan tidak adanya perbedaan sub populasi madidihang di perairan Samudra Hindia bagian Barat dengan Samudra pasifik bagian Barat. Chiang et al. (2008) melaporkan hasil penelitian struktur populasi tuna mata besar antara di perairan kepulauan Cocos, Samudra Hindia timur laut, Samudra Hindia Barat daya dan perairan Seychelles menunjukkan tidak terdapat perbedaan struktur populasi. Hasil penelitian
Dammannagoda et al. (2008) menunjukkan variasi genetik dalam individu madidihang di sekitar perairan Srilanka relatif tinggi sebesar $87,15 \%$.

Berdasarkan IOTC (2015), daerah pemijahan madidihang di Samudra Hindia berada pada area ekuator $0^{\circ}-10^{\circ}$ Lintang Selatan, dengan lokasi utama memijah di Samudra Hindia bagian Barat (pada bujur timur $75^{\circ}$ ), sedangkan daerah mencari makanan berada pada sekitar laut Arabia. Rekonstruksi pohon filogenetik menunjukan adanya pencampuran populasi madidihang pada dua populasi di Laut Maluku (Akbar et al., 2014). Penelitian ini bertujuan untuk memperoleh informasi keragaman genetik dan struktur populasi yang dieksploitasi dan kekerabatan populasi madidihang di perairan Indonesia, yaitu di WPP 572 (Samudra Hindia Barat Sumatera), WPP 573 (Samudra Hindia Selatan Bali) dan WPP 715 (Perairan Sulawesi Utara).

\section{BAHAN DAN METODE Pengumpulan Data}

Pengumpulan sampel genetik madidihang ( $T$. albacares) dilakukan melalui survey laut dengan kapal rawai tuna yang beroperasi di Samudra Hindia Barat Sumatera (WPP 572), Samudra Hindia Selatan Bali (WPP 573), serta dilakukan di Pangkalan Pendaratan Ikan (PPI) di Sulawesi Utara (WPP 715) (Gambar 1). Data genetik (DNA) diperoleh dari sampel jaringan yang diambil dari bagian ujung sirip ekor ikan melalui analisis microsatellite. Analisis dilakukan masingmasing terhadap 10 sampel genetik dari ketiga lokasi tersebut (Tabel 1).

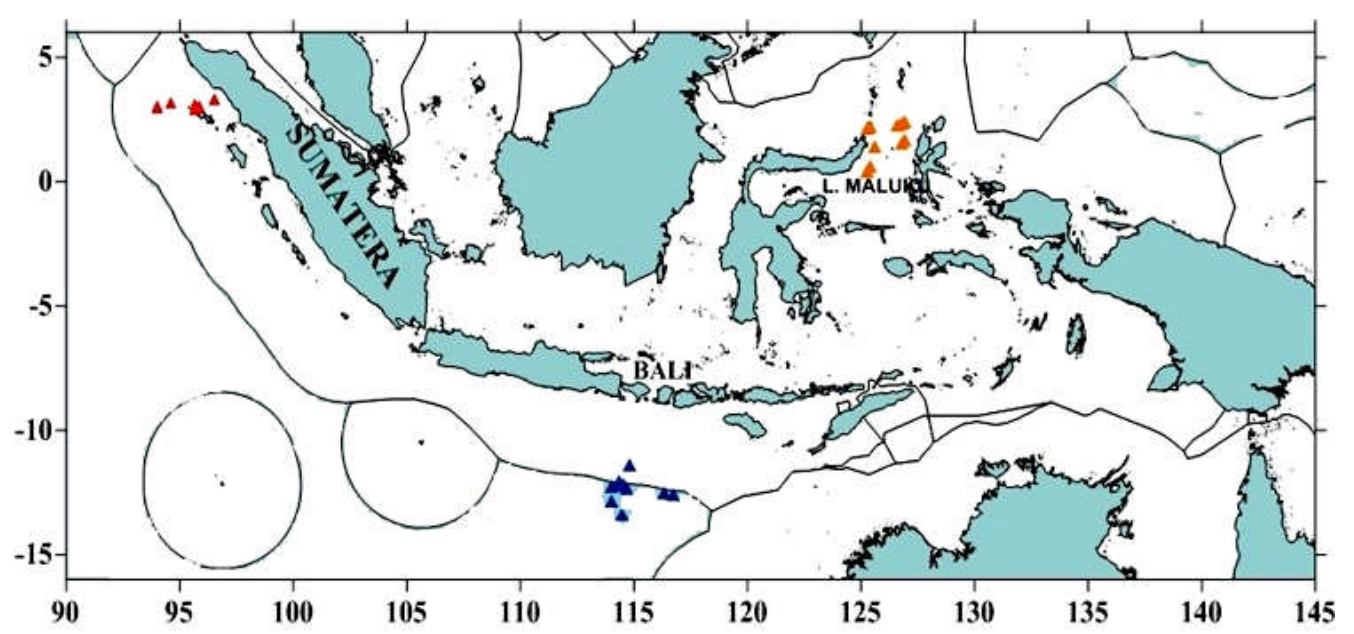

Gambar 1. Lokasi pengambilan sampel genetik madidihang (Thunnus albacares), ditunjukkan dengan warna merah (Barat Sumatera), biru (Selatan Bali) dan oranye (Perairan Sulawesi Utara).

Figure 1. Location of yellowfin tuna (Thunnus albacares) genetic sample collection, shown with red (West of Sumatera), blue (South of Bali) and orange color (North Sulawesi Waters). 
Tabel 1. Sampel madidihang dari ketiga lokasi

Table 1. Yellowfin tuna samples from three locations

\begin{tabular}{lcccc}
\hline \multicolumn{1}{c}{$\begin{array}{c}\text { Lokasi } \\
\text { Location }\end{array}$} & $\begin{array}{c}\text { Kelompok } \\
\text { Group }\end{array}$ & $\begin{array}{c}\text { Lintang } \\
\text { Latitude }\end{array}$ & $\begin{array}{c}\text { Bujur } \\
\text { Longitude }\end{array}$ & $\begin{array}{c}\text { Panjang cagak } \\
\text { rata-rata (cm) } \\
\text { Average fork } \\
\text { length (cm) }\end{array}$ \\
\hline $\begin{array}{l}\text { Samudra Hindia Barat } \\
\begin{array}{l}\text { Sumatera } \\
\text { Samudra Hindia Selatan }\end{array}\end{array}$ & $1(\mathrm{n}=10)$ & $2,85-3,24^{\circ}$ LU & $94,03-96,54^{\circ} \mathrm{BT}$ & 110,8 \\
$\begin{array}{l}\text { Bali } \\
\text { Perairan Sulawesi Utara }\end{array}$ & $3(\mathrm{n}=10)$ & $11,5-13,5^{\circ}$ LS & $114,02-116,71^{\circ} \mathrm{BT}$ & 141,7 \\
\hline
\end{tabular}

\section{Analisis Laboratorium}

Analisis laboratorium terdiri dari ekstraksi, purifikasi, amplifikasi PCR dan elektroforesis. Ekstraksi DNA dalam penelitian ini mengikuti prosedur chelex karena tahapannya lebih cepat dan mengurangi risiko kontaminasi (Walsh et al., 1991). Purifikasi genom DNA menggunakan metode manual yang ada dalam PrepEase DNA Clean-Up Kit. Genom DNA hasil ekstrkasi diambil $100 \mu \mathrm{l}$ dan dimasukkan ke eppendorf tube ditambah $500 \mu \mathrm{l}$ binding buffer (PBI). Dengan finger fortex larutan akan tercampur dan di flashing.

\section{Analisis Data}

Hasil produk amplifikasi PCR dengan penanda DNA mikrosatelit dianalisis dengan menggunakan program GeneMapper 4.0 setelah proses elektroforesis dalam mesin AppliedBiosystems. Hal ini diperlukan untuk memperjelas hasil interpretasi ukuran fragmen-fragmen (alel) DNA yang muncul dari masing-masing genom DNA. Data yang diperoleh selanjutnya digunakan untuk mengukur beberapa parameter genetik populasi meliputi: jumlah alel, frekuensi alel, heterozigositas, variabilitas $(\mathrm{Ho} / \mathrm{He})$, jarak genetik, variasi molekuler, hubungan kekerabatan dan struktur populasi. Perhitungan data genetik dilakukan dengan menggunakan bantuan perangkat lunak program GenAIEx versi 6.5 (Peakall \& Smouse, 2012) dan program Arlequin versi 3.11 (Excoffier et al., 2005).

Kekerabatan antar populasi ditentukan berdasarkan parameter jarak genetik yang dihitung menurut Nei (1972) dengan persamaan:

$$
D=-\ln \left[\frac{J_{a b}}{\left\{\left(J_{a} x J_{b}\right)^{0,5}\right\}}\right]
$$

Dimana;

$D \quad=$ jarak genetik
$J_{a b} \quad=$ frekuensi alel pada lokus dengan populasi yang sama

$J_{a} \& J_{b}=$ frekuensi alel pada populasi $A$ dan $B$

Derajat perbedaan molekuler haplotipe di antara populasi diduga dengan menggunakan Analysis of Moleculer Varians (AMOVA) dan uji jarak berpasangan $(F s t)$ dengan persamaan:

$F_{s t}=1-\left(\frac{H_{w}}{H_{b}}\right)$

Dimana;

$F_{s t}=$ indeks diferensiasi

$H_{w}^{s t}=$ rata-rata perbedaan intra populasi

$H_{b}=$ rata-rata perbedaan antar populasi

\section{HASIL DAN BAHASAN Hasil}

Sampel jaringan masing-masing diamplifikasi dengan 3 loci mikrosatelit yaitu Ttho- $1^{*}$, Ttho- $4^{*}$ dan Ttho- $7^{*}$. Distribusi ukuran alel sampel madidihang lokus DNA mikrosatelit Ttho-1* memiliki kisaran 175 - $191 \mathrm{bp}$, sedangkan pada lokus Ttho- $4^{*}$ memiliki kisaran 140 - 152 bp dan lokus Ttho-7* memiliki kisaran 188 - 218 bp. Rata-rata jumlah alel yang ditemukan pada semua loci DNA mikrosatelit yaitu 8,5 dan bersifat polimorfik relatif tinggi (Takagi et al., 1999). Hasil penelitian Moria et al. (2009), semua loci yang digunakan (Ttho-1* ${ }^{*}$, Ttho- $4^{*}$ dan Ttho- $7^{*}$ ) bersifat polimorfik pada semua sampel madidihang yang diuji dan secara total ditemukan 102 alel dengan rerata 6 -11 alel per lokus.

Hasil analisis 3 loci DNA mikrosatelit menunjukkan bahwa ketiga kelompok sampel madidihang terdeteksi menghasilkan rata-rata kelimpahan alel 7,2; frekuensi alel 65 dan rata-rata nilai heterozigositas $(\mathrm{Ho})$ 0,68. Lokus Ttho- $7^{*}$ terdeteksi memiliki kelimpahan tertinggi dengan rata-rata 10,7; frekuensi alel 32 dan heterozigositas $(\mathrm{Ho})$ 0,83 (Tabel 2). 
Tabel 2. Kelimpahan, frekuensi dan nilai heterozigositas $(\mathrm{Ho})$ alel pada setiap kelompok sampel dan lokus Table 2. Abundance, frequency and heterozygosity value $(\mathrm{Ho})$ allele in each sample group and locus

\begin{tabular}{|c|c|c|c|c|c|c|c|c|c|c|c|c|c|}
\hline \multirow{2}{*}{\multicolumn{2}{|c|}{$\begin{array}{c}\begin{array}{c}\text { Hasil } \\
\text { Results }\end{array} \\
\text { Kelompok/Group }\end{array}$}} & \multicolumn{4}{|c|}{$\begin{array}{l}\text { Kelimpahan alel } \\
\text { Allele abundance }\end{array}$} & \multicolumn{4}{|c|}{$\begin{array}{l}\text { Frekuensi alel } \\
\text { Allele frequency }\end{array}$} & \multicolumn{4}{|c|}{$\begin{array}{l}\text { Nilai heterozigositas }(\mathrm{Ho}) \\
\text { Heterozigosity value }(\mathrm{Ho})\end{array}$} \\
\hline & & 1 & 2 & 3 & Rerata & 1 & 2 & 3 & Jumlah & 1 & 2 & 3 & Rerata \\
\hline \multirow{3}{*}{ Lokus } & Ttho-1* & 5 & 6 & 5 & 5,3 & 5 & 6 & 5 & 16 & 0,6 & 0,5 & 0,5 & 0,53 \\
\hline & Ttho-4* & 6 & 7 & 4 & 5,7 & 6 & 7 & 4 & 17 & 0,7 & 0,7 & 0,6 & 0,67 \\
\hline & Ttho- $7^{*}$ & 11 & 11 & 10 & 10,7 & 11 & 11 & 10 & 32 & 0,9 & 0,8 & 0,8 & 0,83 \\
\hline \multicolumn{2}{|c|}{ Rerata/Average } & 7,3 & 8,0 & 6,3 & 7,2 & & & & & 0,73 & 0,67 & 0,63 & 0,68 \\
\hline \multicolumn{2}{|c|}{ Jumlah/Total } & & & & & 22 & 24 & 19 & 65 & & & & \\
\hline
\end{tabular}

Perbedaan jarak genetik (genetic distance) dihitung menggunakan metode Pairwise Population Matrix of Nei Genetic Distance dengan bantuan program GenAIEx 6.5. Dari hasil perhitungan diperoleh perbedaan jarak genetik antara kelompok sampel

Tabel 3. Jarak genetik antara kelompok sampel madidihang

Table 3. Genetic distance among yellowfin sample groups madidihang seperti ditunjukkan pada Tabel 3. Kelompok sampel madidihang di Barat Sumatra memiliki jarak yang relatif jauh dengan kelompok sampel madidihang di Perairan Sulawesi Utara.

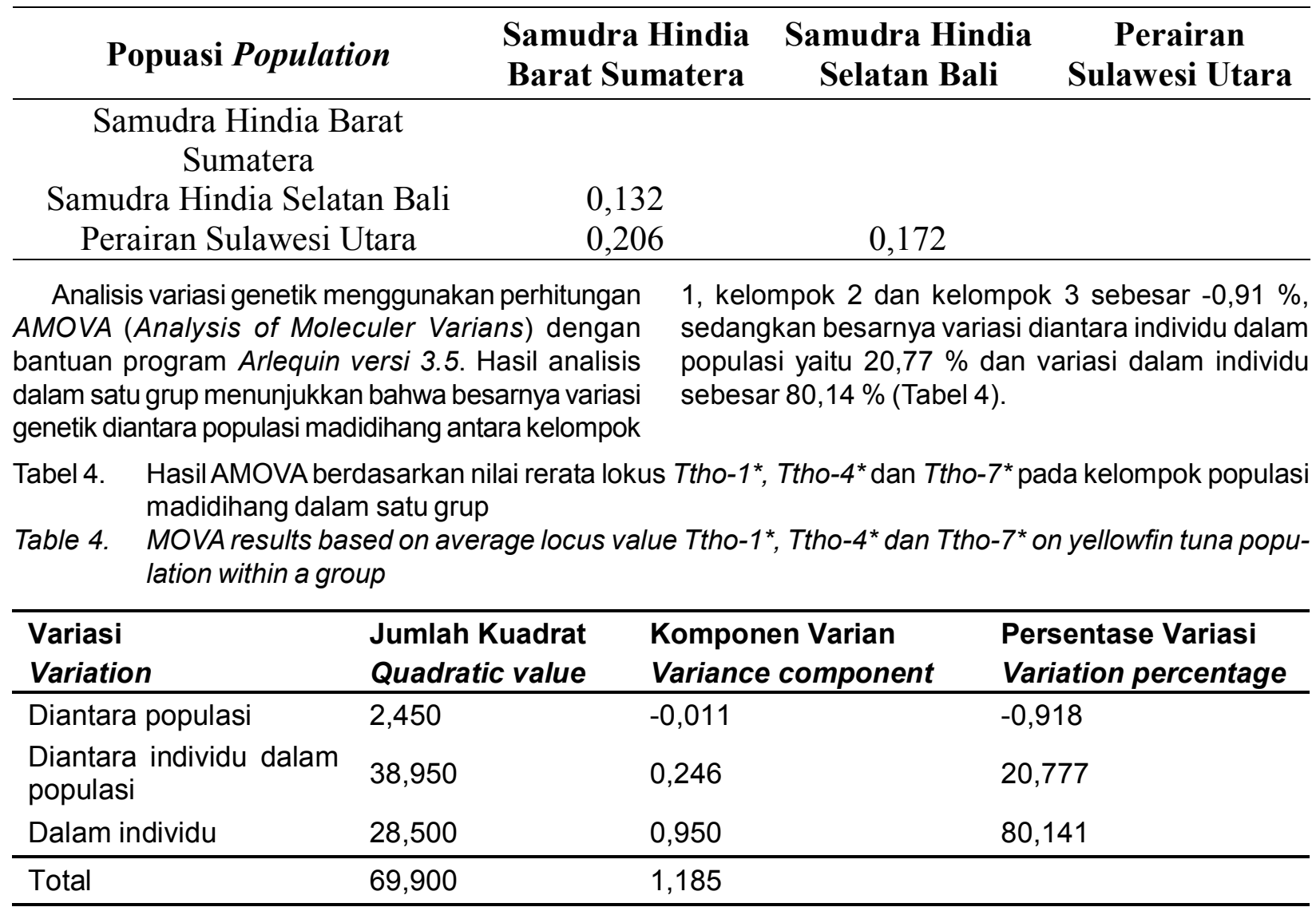

Data keragaman alel pada semua kelompok sampel genetik dianalisis menggunakan uji perbandingan sampel genetik populasi (comparisons of population samples). Hasil perhitungan F-statistik berupa nilai rata-rata FIT; FST dan FIS secara berurutan yaitu 0,$19859 ;-0,00918$ dan 0,20588 . Nilai FIT tersebut menunjukkan tingkat keseluruhan dari perkawinan sedarah yang terjadi pada total populasi berkisar $19 \%$, nilai FST menunjukkan derajat perkawinan sedarah pada subpopulasi dari total populasi sebesar $-0,9 \%$ dan nilai FIS menunjukkan besarnya perkawinan sedarah oleh individu yang terjadi pada suatu subpopulasi sebesar $20 \%$.

Hasil uji statistik pada signifikan $95 \%(0,05)$ untuk mengetahui perbedaan struktur populasi pada masingmasing kelompok sampel madidihang berdasarkan nilai $P$ dari FST menunjukkan bahwa ketiga kelompok 
populasi tersebut tidak berbeda nyata (nilai $P>0,05$ ) (Tabel 5). Hal ini mengindikasikan bahwa struktur genetik diantara tiga populasi yang diamati adalah lemah (atau sangat lemah) akibat relatif tingginya aliran gen.

Tabel 5. Matriks Fst (di bawah diagonal) dan p-values (di atas diagonal) diantara sampel populasi madidihang Table 5. Matrix Fst (below diagonal) and p-values (above diagonal) among yellowfin tuna population sample

\begin{tabular}{clcl}
\hline $\begin{array}{c}\text { Populasi } \\
\text { Population }\end{array}$ & \multicolumn{1}{c}{$\begin{array}{c}\text { Kelompok 1 } \\
\text { Group 1 }\end{array}$} & \multicolumn{1}{c}{$\begin{array}{c}\text { Kelompok 2 } \\
\text { Group 2 }\end{array}$} & \multicolumn{1}{c}{$\begin{array}{c}\text { Kelompok 3 } \\
\text { Group 3 }\end{array}$} \\
\hline Kelompok 1/Group 1 & - & 0,8507 & 0,3598 \\
Kelompok 2/Group 2 & 0,0024 & - & 0,6888 \\
Kelompok 3/Group 3 & 0,0037 & 0,0034 & - \\
\hline
\end{tabular}

\section{Bahasan}

Distribusi ukuran alel atau panjang fragmen sampel DNA madidihang bervariasi dari $182-195 \mathrm{bp}$ (base pairs) pada lokus Ttho-1*, 131 - 150 bp pada lokus Ttho- $4^{*}$ dan $197-239$ bp pada lokus Ttho- $7^{*}$. Hasil penelitian Takagi et al. (2003), distribusi ukuran alel sampel DNA madidihang pada lokus mikrosatelit Ttho-1* memiliki kisaran 175 - $191 \mathrm{bp}$, sedangkan pada lokus Ttho- $4^{*}$ memiliki kisaran $140-152 \mathrm{bp}$ dan lokus Ttho- $7^{*}$ memiliki kisaran $188-218$ bp. Semua lokus yang digunakan (Ttho- $1^{*}$, Ttho- $4^{*}$ dan Ttho- $7^{*}$ ) bersifat polimorfik tinggi pada semua sampel madidihang yang diuji dan secara total ditemukan 102 alel dengan rerata $6-11$ alel per lokus. Tingkat polimorfisme yang tinggi dapat memberikan informasi mengenai keragaman genetik yang lebih baik daripada penggunaan penanda yang lain (Moria et al., 1999). Perbedaan penanda DNA yang digunakan dan jumlah sampel yang dianalisis dapat mempengaruhi sebaran ukuran alel dan rata-rata jumlah alel yang terdeteksi.

Nilai rata-rata heterozigositas $(\mathrm{He})$ pada kelompok sampel madidihang di Samudra Hindia Barat Sumatera yaitu 0,773 , sedangkan kelompok populasi madidihang di Samudra Hindia Selatan Bali sebesar 0,835 dan kelompok populasi madidihang di Bitung sebesar 0.757 . Jika nilai $H e$ antara 0 sampai $<0,5$ maka termasuk keragaman genetiknya rendah, sedangkan nilai $\mathrm{He}>0,5$ sampai 1,0 maka keragaman genetiknya tinggi (Nei, 1978; Akbar et al., 2014). Ketiga nilai $\mathrm{He}$ tersebut menunjukkan bahwa populasi madidihang mempunyai tingkat keragaman genetik yang relatif tinggi dengan nilai rata-rata $\mathrm{He}$ untuk kedua kelompok populasi di Samudra Hindia adalah 0,804 . Nilai He madidihang di Samudra Hindia Barat Sumatera lebih kecil dibandingkan madidihang di Samudra Hindia Selatan Bali sehingga perlu mendapat perhatian agar tidak mengalami penurunan keragaman genetik. Hasil penelitian Moria et al. (2009), menunjukkan keragaman genetik yang tinggi pada madidihang di perairan utara Bali berdasarkan sampel larva sebesar 0,878 . Wu et al. (2010) menjelaskan bahwa keragaman genetik madidihang sebesar 0,992 di Samudra Pasifik bagian Barat dan 0,999 di Samudra Hindia bagian Barat, serta Kunal \& Kumar (2013) memperoleh keragaman genetik madidihang sebesar 0,998. Dammannagoda et al. (2008), menunjukkan nilai keragaman madidihang di Samudra Hindia perairan Srilanka berkisar 0,794 0,896 . Zardoya et al. (2004) mengatakan keragaman genetik yang tinggi pada tuna merupakan tipe pola genetik ikan famili Scrombridae.

Tingginya keanekaragaman genetik spesies ikan laut seperti madidihang disebabkan karakteristik ukuran populasi yang besar dan distribusi yang luas di seluruh dunia (Chiang et al., 2008). Selain itu, faktor kemampuan migrasi yang tinggi dimana migrasi akan menyebabkan terjadinya perkawinan silang dan percampuran gen antar populasi. Pernyataan ini didukung oleh Ely et al. (2005) yang melaporkan bahwa kemampuan migrasi ikan tuna yang tinggi berbanding lurus dengan spesies lainnya sehingga memberikan peluang untuk bertemu dan mengakibatkan terjadi persilangan genetik yang tinggi. Semakin banyak lokus atau penanda DNA yang digunakan dan variasi kelompok sampel genetik yang dianalisis, maka semakin bervariasi kisaran nilai keragaman genetik yang diperoleh.

Menurut Akbar et al. (2014), populasi tuna yang menyebar secara luas mengakibatkan penangkapan madidihang hanya pada sub yang berjumlah kecil pada suatu perairan. Zona migrasi yang luas pada ikan tuna memberikan peluang adanya pertemuan antar populasi dan menutup kemungkinan terjadinya inbreeding (perkawinan sedarah) di dalam populasi, sehingga dengan demikian pola genetik ikan tuna akan beragam dan menyebabkan tingginya keragaman genetik.

Populasi dengan keragaman genetik yang tinggi memiliki peluang hidup yang lebih baik karena setiap gen memiliki respon yang berbeda-beda terhadap kondisi lingkungan. Kehadiran berbagai macam gen 
dari individu-individu di dalam populasi menambah kemampuan populasi dalam merespon perubahan lingkungan. Upaya untuk mempertahankan agar kondisi populasi madidihang di Samudra Hindia tidak mengalami penurunan keragaman genetik, harus terus dilakukan, sehingga diperlukan manajemen atau pengelolaan perikanan tuna yang baik (IOTC, 2015).

Jarak genetik antar kelompok sampel madidihang di Samudra Hindia relatif dekat yaitu 0,132, dibandingkan jarak genetik dengan perairan Sulawesi Utara berkisar 0,172-0,206. Jarak genetik merupakan ukuran perbedaan genetik antar populasi atau famili yang dihitung berdasarkan frekuensi alel (Nei, 1978). Semakin kecil jarak genetik antar individu dalam populasi, maka populasi tersebut semakin seragam (Koh et al., 1999).

Adanya perbedaan jarak genetik tersebut menunjukkan adanya dua kelompok genetik yang berbeda antara populasi madidihang di Samudra Hindia (kelompok 1 dan 2) dengan di sekitar perairan Sulawesi Utara (kelompok 3). Pertiwi et al. (2014) menjelasan bahwa analisis jarak genetik dengan metode perhitungan Tamura-Nei juga menunjukkan ada dua kelompok genetik berbeda populasi tuna mata besar di kawasan Indo-Pasifik, yaitu Samudra Hindia dan sekitar perairan Samudra Pasifik. Hasil uji statistik menunjukkan tidak ada perbedaan signifikan jarak genetik baik antara kedua populasi madidihang di Samudra Hindia (kelompok 1 dan 2). Nilai jarak genetik yang relatif kecil antara kelompok 1 dan 2, menunjukkan kedekatan populasi madidihang di Samudra Hindia Barat Sumatera dengan Samudra Hindia Selatan Bali. Kedua kelompok sampel tersebut secara geografis tidak terbatas antara satu dengan yang lainnya. Keadaan ini menyebabkan proses migrasi dan pertukaran gen antar kelompok sampel dapat terjadi.

Hasil ini juga didukung dari variasi genetik antara populasi madidihang kelompok 1 (satu) dan kelompok 2 (dua) relatif kecil yaitu $-0,91 \%$, yang menunjukkan bahwa populasi madidihang tersebut memiliki hubungan kekerabatan yang dekat dan masih dalam satu struktur populasi (belum terpisah menjadi subpopulasi). Hasil penelitian Kunal et al. (2014) menggunakan mitokondria DNA pada sampel madidihang di sekitar perairan India dan Srilanka, menunjukkan tidak adanya perbedaan struktur populasi madidihang Beberapa studi penelitian lainnya tentang struktur populasi madidihang di wilayah Samudra Hindia bagian Barat dan Timur menunjukkan tidak ditemukan hasil yang signifikan perbedaan subpopulasi (Chow et al., 2000; Nishida et al., 2001).
Hartl \& Clarke (1997) membagi nilai Fst menjadi 4 tingkatan perbedaan genetik yaitu rendah $(<0,05)$, sedang $(0,05-0,15)$, tinggi $(0,15-0,25)$ dan sangat tinggi $(>0,25)$. Berdasarkan kriteria tersebut, nilai Fst penelitian ini pada kisaran 0,0024-0,0037 dikategorikan memiliki perbedaan genetik yang rendah. Selanjutnya, nilai $p$-value pada kisaran 0,3598-0,8507 juga menunjukkan tidak ada perbedaan yang signifikan pada ketiga kelompok madidihang di Barat Sumatera, Selatan Bali dan Perairan Sulawesi.

Populasi madidihang pada wilayah Samudra Hindia dan di sekitar perairan Sulawesi Utara (mewakili Samudra Pasifik bagian Barat) juga tidak memiliki perbedaan struktur populasi secara signifikan, walaupun berdasarkan analisis pendekatan jarak genetik terdapat dua kelompok genetik yang berbeda. Wu et al. (2010) menyatakan bahwa tidak ada perbedaan signifikan sub populasi madidihang di perairan Samudra Hindia bagian Barat dengan Samudra pasifik bagian Barat, menggunakan analisis mtDNA. Hasil penelitian Aquila et al. (2015) menjelaskan bahwa ada signifkan perbedaan struktur populasi madidihang antara di sekitar perairan Filipina dan Laut Bismarck (Papua New Guinea).

\section{KESIMPULAN}

Struktur genetik diantara tiga populasi madidihang yang diamati relatif lemah akibat tingginya aliran gen. Hal ini dapat menjadi indikasi bahwa madidihang di perairan Indonesia merupakan stok tunggal dan terjadi perkawinan acak. Meskipun demikian, sebagai spesies yang bermigrasi jauh lintas negara, pengelolaan madidihang juga memerlukan kerjasama yang baik antar negara yang tergabung dalam organisasi pengelolaan perikanan tuna regional. Diperlukan studi lebih lanjut dengan menggunakan metode penanda (tagging) untuk mengetahui pola migrasi madidihang di Perairan Indonesia.

\section{PERSANTUNAN}

Penelitian ini dibiayai dari DIPA kegiatan riset Loka Riset Perikanan Tuna (LRPT) pada tahun 2016. Peneliti mengucapkan terima kasih kepada Prof. Haryanti dan Ibu Sari Sembiring, M. Biotech dari BBRBLPP, Gondol, Bali serta saudara Abram Barata, S.Pi. sebagai analis di Laboratorium Genetik LRPT yang membantu dalam analisis pada penelitian ini. Peneliti juga mengucapkan terima kasih kepada para pemantau ilmiah LRPT Benoa yang telah membantu dalam proses pengumpulan sampel genetik madidihang. 


\section{DAFTAR PUSTAKA}

Akbar, N., Zamani, N.P., \& Madduppa, H.H. (2014). Keragaman genetik ikan tuna sirip kuning (Thunnus albacares) dari dua populasi di Laut Maluku, Indonesia. Jurnal Depik. 3(1), 65-73.

Chiang, H.C., Hsu, C.C., Wu, G.C.C., Chang, S.K., \& Yang, H.Y. (2008). Population structure of bigeye tuna (Thunnus obesus) in the Indian Ocean inferred from mitochondrial DNA. Fisheries $R e-$ search. 90, 305-312.

Chow, N., Hazama, K., Nishida, T., Ikame, S., Kurihara, S. (2000). A preliminary genetik analysis on yellowfin tuna stock structure in the Indian Ocean using mitochondrial DNA variation. Proc. IOTC. 3, 312-316.

Dammannagoda, S.T., Hurwood, D.A., \& Peter, B.M. (2008). Evidence for fine geographical scale heterogeneity in gene frequencies in yellowfin tuna (Thunnus albacares) from the north Indian Ocean around Sri Lanka. Fisheries Research. 90, 147157.

Ely, B., Vinas, J., Bremer, J.R.A., Black, D., Lucas, L., Covello, K., Labrie, A.V., \& Thelen E. (2005). Consequences of the historical demography on the global population structure of two highly migratory cosmopolitan marine fishes: the yellowfin tuna (Thunnus albacares) and the skipjack tuna (Katsuwonus pelamis). BMC Evolutionary Biology. 5(19), 1-9.

Excoffier L., Laval, G., \& Schneider, S. (2005). Arlequin ver. 3.0: an integrated software package for population genetiks data analysis. Evol Bioinform. 1, 47-50.

Hartl, D.L. \& Clark, A.G. (1997). Principles of population genetics, Fourth edition (p. 635). Sunderland, Massachusetts: Sinauer Associates, Inc. Publishers.

Indian Ocean Tuna Commission (IOTC). (2015). Report of the $17^{\text {th }}$ Session of the IOTC Working Party on Tropical Tunas. IOTC-2015-WPTT17-R[E]. 102 pp.

Koh, Y.H., Popova, E., Thomas, U., Griffith, L.C. \& Budnik, V. (1999). Regulation of DLG localization at synapses by CaMKII-dependent phosphorylation. Cell. 98(3), 353-363.
Kunal, S.P., Kumar, G., \& Menezes, M.R. (2014). Genetik variation in yellowfin tuna (Thunnus albacares) (Bonnaterre, 1788) along Indian Coast using PCR-RFLP analysis of mitochondrial Dna D-Loop Region. International Journal of Scientific Research, 3(1), 25-30.

Kunal, S.P. \& Kumar, G. (2013). Cytochrome oxidase $\mathrm{I}(\mathrm{COI})$ sequence conservation and variation patterns in the yellowfin and longtail tunas. International Journal Bioinformation Research, 9(3), 301309.

Moria, S.B., Permana, G.N., \& Hutapea, J.H. (2009). Karakterisasi Tiga Lokus Mikrosatelit Pada Telur dan Larva Tuna Sirip Kuning, Thunnus albacares. Jurnal Perikanan. XI (2), 144-149.

Nei, M. (1972). Genetik distance between populations. The American Naturalist. 106(949), 283-292.

Nishida, T., Chow, S., Ikame, S., \& Kurihara, S. (2001). RFLP analysis on single copy nuclear gene loci in yellowfin tuna (Thunnus albacares) to examine the genetik differentiation between the western and eastern samples from the Indian Ocean. Proc. IOTC 4, 437-441.

Nugraha, B., Baskoro, M.S., Pane, A.B. \& Nugroho, E. (2010). Genetik diversity of bigeye tuna (Thunnus obesus) based on rntDNA analysis with the PCRRFLP technique. Ind.Fish.Res.J. 16(1), 25-32.

Peakall, R. \& Smouse, P.E. (2012). GenAIEx 6.5: genetic analysis in Excel. Population genetic software for teaching and research-an update. Bioinformatics. 28, 2537-2539.

Pertiwi, N.P.T., Sembiring, A., Mahardini, A., Cahyani, N.K.D., Anggoro, A.W., Nugraha, B., Sulistyaningsih, R.K., Jatmiko, I., \& Mahardika, I.G.N.K. (2014). Struktur populasi tuna mata besar (Thunnus obesus) di kepulauan Indo-Malaya: analisis control region, DNA mitokondria. Naskah Lengkap Simposium Nasional Pengelolaan Perikanan Tuna Berkelanjutan. Bali $10-11$ Desember 2014.

Santos, S., Hrbek, T., Farias, I.P., Schneider, H., \& Sampaio, I. (2006). Population genetic structuring of the king weakûsh, Macrodon ancylodon (Sciaenidae), in Atlantic coastal waters of South America: deep genetik divergence without morphological change. Molecular Ecology, 15, 4361-4373. 
Takagi, M. (1999). PCR primers for microsatellite loci in tuna species of the genus Thunnus and its application for population genetic study. Fisheries Science. 65(4), 571-576.

Wu, G.C.C., Chiang, H.C., Chou, Y.W., Wong, W.R., Chen, C.C. \& Yang, H.Y. (2010). Phylogeography of yellowfin tuna (Thunnus albacares) in the Western Pacific and the Western Indian Oceans inferred from mitochondrial DNA. Fisheries Research, 105, 248-253.
Zardoya, R., Castilho, R., Grande, C., Favre-Krey, L., Caetano, S., Marcato, S., Krey, G., \& Patarnello, T. (2004). Differential population structuring of two closely related fish species, the mackerel (Scomber scombrus) and the chub mackerel (Scomber japonicus), in the Mediterranean Sea. Moleculer Ecology, 13, 1785-1798. 